Biofouling

2019, Volume 35, Issue 5, Pages 585-595

https://doi.org/10.1080/08927014.2019.1624727

https://archimer.ifremer.fr/doc/00505/61686/

\title{
The oceans are changing: impact of ocean warming and acidification on biofouling communities
}

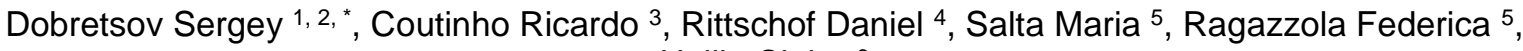 \\ Hellio Claire ${ }^{6}$
}

${ }^{1}$ Marine Science and Fisheries Department, College of Agricultural and Marine Sciences, Sultan Qaboos University, Sultanate of Oman

${ }^{2}$ Centre of Excellence in Marine Biotechnology, Sultan Qaboos University, Sultanate of Oman

3 Instituto de Estudos do Mar Almirante Paulo Moreira, Praia dos Anjos, Arraial do Cabo, RJ, Brazil

4 Nicholas School, Duke University Marine Laboratory, Beaufort USA

${ }^{5}$ School of Biological Sciences, University of Portsmouth, Portsmouth, UK

${ }^{6}$ Laboratoire des Sciences de I'Envionnement Marin (LEMAR), Université de Brest, CNRS, IRD, Ifremer, Plouzané, France

*Corresponding author : Sergey Dobretsov, email address : sergey dobretsov@yahoo.com

\begin{abstract}
:
Climate change (CC) is driving modification of the chemical and physical properties of estuaries and oceans with profound consequences for species and ecosystems. Numerous studies investigate CC effects from species to ecosystem levels, but little is known of the impacts on biofilm communities and on bioactive molecules such as cues, adhesives and enzymes. CC is induced by anthropogenic activity increasing greenhouse emissions leading to rises in air and water temperatures, ocean acidification, sea level rise and changes in ocean gyres and rainfall patterns. These environmental changes are resulting in alterations within marine communities and changes in species ranges and composition. This review provides insights and synthesis of knowledge about the effect of elevated temperature and ocean acidification on microfouling communities and bioactive molecules. The existing studies suggest that CC will impact production of bioactive compounds as well as the growth and composition of biofouling communities. Undoubtedly, with CC fouling management will became an even greater challenge.
\end{abstract}

Keywords : Biofilm, Biofouling, Bioactive compounds, Climate change 


\section{Introduction}

The carbon dioxide concentration in the Earth's atmosphere is clearly and steadily rising (IPCC 2013). Anthropogenic emission has driven $\mathrm{CO}_{2}$ concentration in the atmosphere from $208 \mathrm{ppm}$ during the pre-industrial era to well over $400 \mathrm{ppm}$ at the Hawaii monitoring site since 2015 with an estimated increase of $2 \mathrm{ppm}$ per year (https://www.esrl.noaa.gov/gmd/ccgg/trends/weekly.html). This increase in $\mathrm{CO}_{2}$ concentration in the atmosphere causes many physical consequences for marine environments including ocean warming (IPCC 2013). Over the last 39 years, the mean global sea surface temperature is increasing at an average rate of $>0.1^{\circ} \mathrm{C}$ per decade, with the strongest warming trends found at high latitudes, and with an estimated increase of $2.7^{\circ} \mathrm{C}$ by 2090 . Temperature variations are often accompanied by changes in salinity due to reduced or enhanced precipitation relative to evaporation. Freshening and warming cause enhanced density stratification (IPCC 2013) and reduce the depth of winter mixing, which causes a decrease in $\mathrm{O}_{2}$ concentration in Oxygen Minimum Zones to greater extent than the estimated decrease in $\mathrm{O}_{2}$ concentration in the Open Ocean (mean rate of 0.1 to $>0.3 \mu \mathrm{mol} \mathrm{Kg}^{-1} \mathrm{yr}^{-1}$ ) (IPCC 2013). Additionally, climate change is expected to increase upwelling frequency and intensity, lead to sea level rise due to thermal expansion, melting of sea ice and glaciers (Doney et al. 2012).

Increase in the level of atmospheric $\mathrm{CO}_{2}$ is leading to ocean acidification (Doney et al. 2009). Because the oceanic and atmospheric gas concentrations tend towards equilibrium, $30 \%$ of the added atmospheric $\mathrm{CO}_{2}$ has been taken up by the oceans, decreasing the average $\mathrm{pH}$ by $\sim 0.1 \mathrm{pH}_{\mathrm{T}}$ unit and ultimately changing water chemistry. The observed decrease in $\mathrm{pH}_{\mathrm{T}}$ corresponds to a $26 \%$ increase in the hydrogen ion 
concentration of seawater (Feely et al. 2009). By 2100, $\mathrm{pH}$ is expected to change by -0.13 (421ppm under RCP2.6), -0.22 (538ppm under RCP4.5), -0.28 (670ppm under RCP6.0) and $-00.42 \mathrm{pH}_{\mathrm{T}}$ unit (936ppm under RCP8.5). Progress has been made to understand the consequences of changes in $\mathrm{pH}$, carbonate $\mathrm{CO}_{3}{ }^{2-}$, and the saturation state of $\mathrm{CaCO}_{3}$ for marine organisms and ecosystems (IPCC 2013; Wahl et al. 2015). These chemical and physical changes have direct implications for physiological processes such as photosynthesis, calcification, growth rates and internal $\mathrm{pH}$ regulation in a wide range of organisms (McCoy and Ragazzola 2014, Nannini et al. 2015, Evans et al. 2017, Fabricius et al. 2017, Okazaki et al. 2017) which will lead in a disruption of marine ecosystems and a reduction of biodiversity (Hoegh-Guldberg et al. 2007, Milazzo et al. 2014, Beaugrand et al. 2015).

All industrial installations in estuaries, bays, seas and oceans, such as vessels, platforms, and buoys, quickly develop biofouling, a community composed of micro- and macrofouling organisms (Clare et al. 1992). Micro-fouling usually presents as a dynamic microbial biofilm, which is composed of various species of bacteria, microalgae and protozoa incorporated in a muco-polysaccharide matrix (Dobretsov 2010; Malaeb et al. 2013; Salta et al. 2013). Macro-fouling communities are complex, with barnacles, bryozoa, mussels, polychaetes and macroalgae being the most common (Richmond \& Seed 1991; Zardus et al. 2008). In some cases, micro-fouling organisms produce chemical cues that induce or inhibit settlement of macro-fouling species (Crisp 1984; Dobretsov et al. 2006; Hadfield 2011; Qian et al. 2007; Rittschof 2017) while in others there is a little direct relationship between macro- and micro-fouling. 
Biofouling has a huge economic impact on maritime industries (Callow \& Callow 2002; Trepos et al. 2014). Biofouling clogs aquaculture nets, water intakes, heat exchangers and reduces ship hull performance (Okamura et al. 2010; Schultz et al. 2011; Sievers et al. 2014). Moreover, biofouling increases corrosion, shear stress and drag, eventually leading to higher fuel consumption (Schultz et al. 2011) and increased production of $\mathrm{CO}_{2}$ and particulate carbon.

There are numerous reports of the effect of single environmental factors associated with climate change $\left(\mathrm{CO}_{2}\right.$ level, elevated temperatures and acidification) on individual benthic species (Bamber 1990; Parker et al. 2011; Lane et al. 2013; Calosi et al. 2013; Peck et al. 2015). Some of these benthic species, like the blue mussel Mytilus edulis, are important biofouling species. In contrast, the percent of biofouling publications considering climate change is quite low but increasing every year (Figure 1). Several publications report effects of factors associated with climate change on micro- and macro-fouling communities on inert substrates (Kim \& Micheli 2013; Gladis-Schmacka et al. 2014; Peck et al. 2015) and living hosts (Nasrolahi et al. 2012; Stratil et al. 2013; Saderne \& Wahl 2013; Saha et al. 2014).

A significant proportion of the biofouling-related climate change literature addresses invasive species (Stachowicz et al. 2002; Hellmann et al. 2008; Canning-Clode et al. 2011). Invasive species can be introduced by ship fouling and in ballast water (Davidson et al. 2008, 2009; Sorte et al. 2010; Keller et al. 2011). Most biofouling-related climate change literature deals with species (organismal level) or populations of individual species (Figure 2). Fewer researchers investigated potential impact of factors associated with climate change on multispecies communities. The lowest number of publications 
report effects of factors associated with climate change on signaling molecules and the biochemistry of organisms (Poloczanska \& Butler 2009) (Figure 2). The impact of climate change on microbial communities and the bioactive molecules they generate is understudied.

This review focuses on the impacts of elevated temperature and ocean acidification, on biofouling communities. Particular focus is on the effect of factors associated with climate change on bioactive molecules of fouling organisms and growth and composition of microbial communities. Finally, we suggest areas for fruitful future investigation and the implication of climate change on the antifouling industry.

\section{Climate change and bioactive molecules from fouling organisms}

Biologically active molecules are produced by all phyla of marine organisms and play important roles in signaling, communication, allelopathy (Mayer et al. 2013) and organization of marine communities (Browne et al. 1998; Hay 2009; Rittschof 2017). Chemical cues from bacteria, diatoms and fungi induce or inhibit settlement of invertebrate larvae and algal spores (Wieczorek et al. 1996; Zardus et al. 2008; Dobretsov et al. 2013). When released in the marine environment, most of these biologically active molecules are bio-transformed or biodegraded by microbes (Uroz et al. 2005; Moree et al. 2012). There is a straightforward relationship between increase in temperature and the half-life of biologically active molecules (Singh et al. 2004). Similarly, there is a positive relationship between the concentration of heterotrophic bacteria and the half-life of signal molecules (Decho et al. 2010). Elevated water temperatures due to climate change will 
stimulate growth of microorganisms and enhance biodegradation of cues as well as enhance synthesis of antimicrobial compounds by marine fouling organisms (Table 1). Marine bacteria coordinate virulence, competence, conjugation, production of antibiotics, motility, and biofilm formation by quorum sensing (QS) (Miller \& Bassler 2001; Waters \& Bassler 2005; Williams 2007). QS is based on the production, release and detection of chemical signal molecules called autoinducers. Increased concentrations of these signals due to high bacterial population density lead to an alteration in gene expression that regulates bacterial physiological activities (Decho et al. 2011). One of the most common and studied class of QS signal molecules is acyl homoserine lactone (AHL) (Waters \& Bassler 2005). AHLs are unstable at $>\mathrm{pH} 7$ (Yates et al. 2002). Studies assessing the stability of AHL against alkaline hydrolysis showed that AHLs having longer acyl chains (>12 carbons) are more resistant to breakdown than their shorter counterparts (Hmelo et al. 2011). In laboratory and field experiments, $\mathrm{pH}$ has a significant impact on the concentration of AHLs in microbial mats (Decho et al. 2009). In phototrophic microbial mats, short chain AHLs degrade quickly during the day, when the $\mathrm{pH}$ is $>$ 8.2. During the night, when $\mathrm{pH}$ is 6.8 the concentrations of AHLs increases (Decho et al. 2009). When shorter-chain AHLs are degraded too rapidly, cellular communication may be disrupted. Acidification due to climate change will have a dramatic effect on concentrations of AHLs (Table 1). Since AHLs are important for biofilm structure and composition and settlement of some macro-fouling species (Dobretsov et al. 2009), it is possible that changes in production of QS compounds will alter densities and compositions of biofouling communities. 
Enzymes are biological catalysts that accelerate the rate of specific biochemical reactions. Most enzymes are proteins and their structure is important for their activity. Increased temperature and changes in $\mathrm{pH}$ can lead to partial inhibition and in extreme cases to inactivation of enzymes (Iyer \& Ananthanarayan 2008). However, in other cases such as the activity of trypsin-like enzymes (Rittschof, 2017) increased temperature and lowered $\mathrm{pH}$ are near the optimum for the enzymes and increase rates of reactions. When marine organisms are subjected to environmental change (Hochachka \& Somero 2002), the three main mechanisms used to maintain physiological homeostasis are: 1) quantitative (changing the concentration of enzymes and/or reactants); 2) qualitative (using a protein variant); 3) modulation (modifying the protein environment to reduce the impact of environmental change) (Clarke 2003).

Research shows that temperature impacts the enzyme levels and physiology of barnacles (Wong et al. 2011). Water temperature and high anthropogenic pollution have a significant effect on concentrations of antioxidant enzymes, such as catalase, superoxide dismutase and NADH-DT diaphorase, in the barnacle Balanus (=Amphibalanus) amphitrite (Niyogi et al. 2001). Anthropogenic ocean acidification alters protein expression patterns in B. amphitrite (Wong et al. 2011) although past studies have not found effects on reproduction due to changes in $\mathrm{pH}$ (McDonald et al. 2009, Nardone et al., 2018). The impact of temperature and $\mathrm{pH}$ on adhesion of barnacles has been reported (Tedesco et al. 2017).

Similarly, enzymes responsible for calcification of sedentary polychaete tubes were affected by elevated concentrations of $\mathrm{CO}_{2}$ (Chan et al. 2012; Lane et al. 2013). Past work indicates the aragonite-producing juveniles of Hydroides elegans at the level of 
acidification predicted for the years 2050-2300 will not be able to maintain integrity of their calcification products (Chan et al. 2012).

Acidification affects interactions between iron and 3,4-dihydroxyphenylalanine (DOPA) and thus weakens byssus attachment of Mytilus trossulus to non-calcified materials (O’Donnell et al. 2013). Mussel byssus threads were weaker and less extensible when secreted under elevated $\mathrm{pCO}_{2}(>1200 \mu \mathrm{atm})$, whereas shell and tissue growth were unaffected (O'Donnell et al. 2013). Byssal fiber performance was reduced by $40 \%$, which suggest that mussels will be dislodged by forces lower than those which dislodge them under present conditions. Decreased mussel attachment strength due to low $\mathrm{pH}$ was also reported by Zhao et al. (2017) who showed with real time PCR that low pH altered the expression of genes encoding proximal thread matrix protein, precursor collagen proteins and mussel foot proteins. The expression of some genes was down regulated, while others were up regulated. In multi-species communities, the impact of ocean acidification on mussel biomolecules became less predictable. A recent mesocosm study suggested that dense populations of macrophytes, like Fucus vesiculosus and Zostera marina, may mitigate acidification impacts on mussel (Mytilus edulis) calcification by raising mean $\mathrm{pH}$ of seawater (Wahl et al. 2017). In the future, factors associated with climate change can change activity of enzymes and other bioactive molecules and, thus, change physiology and behavior of fouling organisms, and, finally, lead to changes in biofouling communities.

\section{Climate change and microbial communities}


Stress factors associated with climate change affect the growth and productivity of microbes (Rajkumar et al. 2013) and production of bioactive compounds (Hasegawa et al. 2005; Yang et al. 2007). Temperature has a dramatic impact on microbial growth (Price \& Sowers 2004). Elevated temperature accelerates the growth of mesophiles and slows the growth of psychrophiles and alters the interactions between bacteria and their hosts (White et al. 1991; Wahl et al. 2012). In a case of marine pathogens, elevated temperature increases growth, virulence and antimicrobial resistance (Kimes et al. 2012; Abdallah et al. 2014). For example, at $28^{0} \mathrm{C}$ the infection rate and attachment of the coral pathogen Vibrio shiloi increases, while at the lower temperatures (about $16^{0} \mathrm{C}$ ) bacterial adhesion and growth in the tissues of the host coral Oculina patagonica is minimal and does not cause bleaching (Toren et al. 1998; Kushmaro et al. 2001). Virulence factors involved in motility, host degradation, secretion, antimicrobial resistance and transcriptional regulation are up-regulated in the pathogen Vibrio coralliilyticus at temperatures above $27^{0} \mathrm{C}$ (Kimes et al. 2012).

Factors associated with climate change (e.g. increase in temperature, frequency of ElNino and La-Nina-like conditions) and anthropogenically induced eutrophication cause massive algal blooms of microorganisms (Paerl \& Huisman 2009). Due to presence of algal toxins and elevated oxygen consumption these blooms result in massive benthic and fish kills (Richlen et al. 2010; Hallegraeff 2010) and create estuarine and ocean dead zones (Diaz \& Rosenberg 2008). In early July 2008, high level of nutrients and surface temperatures triggered a very dramatic bloom of Ulva sp. occurred in the China Sea off Qingdao, China (Leliaert et al. 2009). Similarly, in January-February 2014 extremely high ocean temperatures on the Atlantic coast of Brazil stimulated the largest algal bloom 
in the country's history. The bloom was composed of several species with the red alga Aglaothamnion uruguayense being the most abundant (Martins et al. 2016). In 2008-2009 in the Persian Gulf, an algal bloom of the dinoflagellate Margalefidinium (Cochlodinium) polycricoides probably brought by ballast waters caused high mortality among benthic animals and fishes (Richlen et al. 2010) and dramatically decreased biomass of biofouling communities (Dobretsov 2015). These examples suggest that algal bloom conditions are becoming the norm for most populated coastal regions and their impact on benthic and fouling community ecosystems will intensify in the warming oceans.

Marine biofilms are communities composed of viruses, bacteria, microalgae and protozoa incorporated in an exopolymer matrix (Zobell \& Allen 1935; Webb et al. 2003; Qian et al. 2007; Dobretsov 2010). Biofilms are dynamic and the composition of communities can be altered by changes in environmental conditions, such as temperature, salinity, $\mathrm{pH}$, and nutrient availability (Qian et al. 2007; Salta et al. 2013). For example, the number of rainy days and temperature affected growth of phototrophic biofilms on roof tiles (Gladis-Schmacka et al. 2014). Researchers studied the effect of different temperatures (high, low and ambient) on formation of microbial biofilms and subsequent larval settlement in laboratory experiments (Lau et al. 2005; Whalan \& Webster 2014). Increased water temperatures led to formation of different microbial communities and subsequently affected settlement of larvae. Compositions of microbial communities associated with the alga Fucus vesiculosus were different when these algae were exposed to different temperatures or light intensities (Saha et al. 2014). Changes in $\mathrm{pH}$ led to significant decreases in biofilm performance and diversity (Patil et al. 2011). Peck and co-authors (Peck et al. 2015) studied formation of biofouling communities under ambient 
$(\mathrm{pH}=7.9)$ and acidified $(\mathrm{pH}=7.7)$ conditions at a constant temperature $\left(23^{0} \mathrm{C}\right)$. After 100 days in acidified conditions, the proportion of sponges and ascidians is increased but numbers of the spirorbid Neodexiospira pseudocorrugata were reduced 5-fold. Changes in $\mathrm{pH}$ affected microfouling communities as well; the densities of the diatoms were lower in the low pH treatments compared to controls (Peck et al. 2015). Similarly, the microbial communities of corals, coralline algae and foraminifera were significantly different after the exposure to $\mathrm{pH} 7.9\left(\mathrm{pCO}_{2}=822 \mu \mathrm{atm}\right)$ over 6 weeks (Webster et al. 2013). In contrast, elevated $p \mathrm{CO} 2$ had no impact on the microbiome associated with rhodoliths (Cavalcanti et al. 2018). If one ventures beyond the host algal thresholds to climate change, positive host-microbiome interactions are disrupted. Increasing temperatures resulted in a 2-fold increase in relative abundance of epibiotic Rhodobacteraceae on the surface of F.vesiculosus (Stratil et al. 2013). Similarly, community diversity measured by evenness and richness was higher at ambient water temperatures than at elevated temperatures. Moreover, intensity of upwelling affects microbes associated with sponges and their bioactive compounds (Batista et al. 2018). Thus, climate change can shift the structure of biofilms on inert and natural substrata (Table 1).

Biofilms play an important role by inducing or suppressing settlement of spores and larvae of some macrofouling species (Dobretsov et al. 2006; Zardus et al. 2008; Hadfield 2011; Salta et al. 2013). Thus, changes in microbial communities due to climate change could alter the structure of macro-fouling communities. For example, in the laboratory microbial communities developed at $23^{\circ} \mathrm{C}$ and $30^{\circ} \mathrm{C}$ were different from ones at $16^{\circ} \mathrm{C}$ (Lau et al. 2005). Larval response to these biofilms was also different; biofilms developed in the laboratory at $23^{\circ} \mathrm{C}$ and $30^{\circ} \mathrm{C}$ stimulated settlement of larvae of the 
barnacle $B$. (=A.) amphitrite and $B$. (=A.) trigonus but had no effect on the polychaete larvae Hydroides elegans (Lau et al. 2005). Similarly, biofilms developed at elevated temperatures stimulated sponge larval settlement (Whalan \& Webster 2014). Changes in the microbial community associated with crustose coralline algae reduced coral larval settlement under low $\mathrm{pH}$ (Webster et al. 2013). UV radiation reduces densities of bacteria in biofilms, which in turn decrease settlement of Hydroides elegans (Dobretsov et al. 2005). These examples show that temperature and $\mathrm{pH}$ associated with climate change

directly affect composition and densities of microorganisms in biofilms and indirectly (through biofilm composition and cues) reduce or enhance larval settlement of macrofouling species.

\section{Conclusions and future research directions}

Climate change and increased anthropogenic activity will have strong effects on microand macro-fouling communities (Figure 3; Table 1). Though there are some publications on impacts of temperature, $\mathrm{pH}$ and generation of bioactive molecules, cues and signals associated with climate change at the species level, there is far less information about the impact of these factors at the community and molecular levels (Figure 2). This review suggests that increased temperatures and ocean acidification can affect bioactive compound production, detection, turnover and, in turn, will have a dramatic effect on microbial and macro-fouling communities.

Reports of the impact of ocean acidification on biofouling communities and their bioactive compounds are contradictory, indicating that responses are community dependent. Acidification will impact aragonite and magnesium calcite producers, such as 
coralline algae, corals, mussels, barnacles and some bryozoans (Doney et al. 2012; Chan et al. 2012; Lane et al. 2013). Acidified conditions significantly change biofouling community composition by a decrease in calcified (tube worms) and an increase in softbodied organisms, like ascidians and sponges (Peck et al. 2015). In contrast, some biofouling species (like Amphibalanus amphitrite and Alcyonidium hirsutum), larvae and proteins are not sensitive to predicted changes in $\mathrm{pH}$ (McDonald et al. 2009; Saderne \& Wahl 2013; Nardone et al., 2018). Moreover, dense populations of macrolagae, like $F$. vesiculosus, may reduce adverse effect of acidification on calcified biofouling organisms (Wahl et al. 2017). Thus, it is likely that ecological impacts of ocean acidification will be location, species and community specific (Ekstrom \& Moser 2014; Ekstrom et al. 2015). Future studies will answer questions about biofouling communities facing ocean acidification.

With climate change fouling management is a challenge (Table 2; Dobretsov 2009). Climate change will affect rates of leaching and dissolution of toxic ions and hydrolysis of copolymers of antifouling coatings because these are temperature, $\mathrm{pH}$ and flow dependent (Yebra et al. 2004; Yebra et al. 2006). Because coating chemistry and release rates are temperature sensitive, meeting environmental regulations in regions, which experience extreme temperatures, will be challenging. Additionally, spreading of invasive species (Sorte et al. 2010) will provide new challenges for industry. Novel regulations that will require coating companies to address these issues and provide new environmentally safe products that are effective in managing fouling in a warming and changing world are urgently needed. 
As the Arctic polar ice melts, fast and inexpensive polar shipping routes are becoming possible (Lasserre \& Pelletier 2011). In the future goods will travel on ships through the Arctic to Europe and Asia. However, the potential impacts of these new routes with respect to introduced and invasive species and performance of antifouling coatings remains unclear (Bax et al. 2003; Ware et al. 2014, Table 2). Long term information on biofouling communities in Arctic and preventive measures are lacking (Zvyagintsev 2003). Several important questions arise: Which invasive species have a chance to establish in warming Arctic waters? Will polar port biofouling communities develop that are comparable to those found in temperate and tropical regions? Will antifouling coatings designed for temperate waters be effective and environmentally benign in warming Arctic? All of these questions should be answered urgently.

To conclude, we are at the beginning of our understanding of impacts of factors associated with climate change on microbes and bioactive molecules. The few existing studies suggest that ocean warming and acidification will have dramatic consequences on biofouling communities and their bioactive compounds. Probably, this effect will be region, community and species specific, which should be priority of future studies.

\section{Acknowledgements}

$\mathrm{RC}$ acknowledges $\mathrm{CNPq}$ Science without Frontier program for SD and $\mathrm{CH}$, and $\mathrm{CNPq}$ for DR travel grant, $\mathrm{CNPq}$ for the Research Productivity Fellowship and INCT-PROOCEANO program. Part of the work of SD was supported by the internal grant IG/AGR/FISH/18/01, the TRC grant RC/AGR/FISH/16/01 and a collaborative grant 
CL/SQU-SA/18/01. $\mathrm{CH}$ and RC acknowledge the EU LEAF (Low Emission AntiFouling) FP7 European project 314697 for financial support. 


\section{References}

Abdallah M, Chataigne G, Ferreira-Theret P, Benoliel C, Drider D, Dhulster P, Chihib NE. 2014. Effect of growth temperature, surface type and incubation time on the resistance of Staphylococcus aureus biofilms to disinfectants. Appl Microbiol Biotechnol. 98:25972607.

Bamber RN. 1990. The effects of acidic seawater on three species of lamellibranch mollusc. J Exp Mar Biol Ecol. 143:181-191.

Batista D, Costa R, Carvalho AP, Batista WR, Rua CPJ, de Oliveira L, Leomil L, Froes AM, Thompson FL, Coutinho R, Dobretsov S. 2018. Environmental conditions affect activity and associated microorganisms of marine sponges. Marine Environmental research. 142: 59-68.

Bax N, Williamson A, Aguero M, Gonzalez E, Geeves W. 2003. Marine invasive alien species: a threat to global biodiversity. Mar Policy. 27:313-323.

Beaugrand G, Edwards M, Raybaud V, Goberville E, Kirby RR. 2015. Future vulnerability of marine biodiversity compared with contemporary and past changes. Nature Climate Change 5:695.

Browne KA, Tamburri MN, Zimmer-Faust RK. 1998. Modelling quantitative structureactivity relationships between animal behaviour and environmental signal molecules. $\mathbf{J}$ Exp Biol. 201:245-258.

Callow ME, Callow JE. 2002. Marine biofouling: a sticky problem. Biol Lond Engl. 49:10-14.

Calosi P, Rastrick SPS, Lombardi C, Guzman HJ de, Davidson L, Jahnke M, Giangrande A, Hardege JD, Schulze A, Spicer JI, Gambi M-C. 2013. Adaptation and acclimatization to ocean acidification in marine ectotherms: an in situ transplant experiment with polychaetes at a shallow CO2 vent system. Philos Trans R Soc B Biol Sci. 368:20120444.

Canning-Clode J, Fowler AE, Byers JE, Carlton JT, Ruiz GM. 2011. “Caribbean Creep" Chills Out: Climate Change and Marine Invasive Species. PLoS ONE. 6:e29657.

Cavalcanti GS, Shukla P, Morris M, Ribeiro B, Foley M, Doane MP, Thompson CC, Edwards MS, Dinsdale EA, Thompson FL. 2018. Rhodoliths holobionts in a changing ocean: host-microbes interactions mediate coralline algae resilience under ocean acidification. BMC Genomics. 19(1):701. doi: 10.1186/s12864-018-5064-4.

Chan VBS, Li C, Lane AC, Wang Y, Lu X, Shih K, Zhang T, Thiyagarajan V. 2012. CO2-Driven Ocean Acidification Alters and Weakens Integrity of the Calcareous Tubes Produced by the Serpulid Tubeworm, Hydroides elegans. PLoS ONE. 7:e42718.

Clare AS, Rittschof D, Gerhart DJ, Maki JS. 1992. Molecular approaches to nontoxic antifouling. Invertebr Reprod Dev. 22:67-76. 
Clarke A. 2003. Costs and consequences of evolutionary temperature adaptation. Trends Ecol Evol. 18:573-581.

Crisp DJ. 1984. Overview of research on marine invertebrate larvae, 1940-1980. In: Marine Biodeterioration: an Interdisciplinary Study. Editors J.D. Costlow and R.C. Tipper. Naval Institute Press. Annapolis MD, pp 103-126.

Davidson IC, Brown CW, Sytsma MD, Ruiz GM. 2009. The role of containerships as transfer mechanisms of marine biofouling species. Biofouling. 25:645-655.

Davidson IC, McCann LD, Sytsma MD, Ruiz GM. 2008. Interrupting a multi-species bioinvasion vector: the efficacy of in-water cleaning for removing biofouling on obsolete vessels. Mar Pollut Bull. 56:1538-1544.

Decho AW, Visscher PT, Ferry J, Kawaguchi T, He L, Przekop KM, Norman RS, Reid RP. 2009. Autoinducers extracted from microbial mats reveal a surprising diversity of Nacylhomoserine lactones (AHLs) and abundance changes that may relate to diel $\mathrm{pH}$. Environ Microbiol. 11:409-420.

Decho AW, Norman RS, Visscher PT. 2010. Quorum sensing in natural environments: emerging views from microbial mats. Trends Microbiol. 18:73-80.

Decho AW, Frey RL, Ferry JL. 2011. Chemical challenges to bacterial AHL signaling in the environment. Chem Rev. 111:86-99.

Diaz RJ, Rosenberg R. 2008. Spreading Dead Zones and Consequences for Marine Ecosystems. Science. 321:926-929.

Dobretsov S. 2009. Expected effect if climate change on fouling communities and its impact on antifouling research. In: Hellio C, Yebra D, editors. Advances in marine antifouling coatings and technologies. Woodhead Publishing, CRC, Cambridge, UK, pp. 222-257

Dobretsov S. 2010. Marine Biofilms. In: Dürr S, Thomason JC, editors. Biofouling: Wiley-Blackwell, p. 123-136.

Dobretsov S. 2015. Biofouling on artificial substrata in Muscat waters. J Agr Mar Sci. 20: 24-29.

Dobretsov SV, Qian P, Wahl M. 2005. Effect of solar ultraviolet radiation on the formation of shallow, early successional biofouling communities in Hong Kong. Mar Ecol Prog Ser. 290:55-65.

Dobretsov S, Dahms H-U, Qian P-Y. 2006. Inhibition of biofouling by marine microorganisms and their metabolites. Biofouling. 22:43-54.

Dobretsov S, Teplitski M, Paul V. 2009. Mini-review: quorum sensing in the marine environment and its relationship to biofouling. Biofouling. 25:413-427. 
Dobretsov S, Abed RMM, Teplitski M. 2013. Mini-review: Inhibition of biofouling by marine microorganisms. Biofouling. 29:423-441.

Doney SC, Fabry VJ, Feely RA, Kleypas JA. 2009. Ocean Acidification: The Other $\mathrm{CO}_{2}$ Problem. Annu Rev Mar Sci. 1:169-192.

Doney SC, Ruckelshaus M, Emmett Duffy J, Barry JP, Chan F, English CA, Galindo HM, Grebmeier JM, Hollowed AB, Knowlton N, et al. 2012. Climate Change Impacts on Marine Ecosystems. Annu Rev Mar Sci. 4:11-37.

Ekstrom JA, Moser SC. 2014. Identifying and overcoming barriers in urban climate adaptation: Case study findings from the San Francisco Bay Area, California, USA. Urban Clim. 9:54-74.

Ekstrom JA, Suatoni L, Cooley SR, Pendleton LH, Waldbusser GG, Cinner JE, Ritter J, Langdon C, van Hooidonk R, Gledhill D, et al. 2015. Vulnerability and adaptation of US shellfisheries to ocean acidification. Nat Clim Change. 5:207-214.

Evans TG, Pespeni MH, Hofmann GE, Palumbi SR, Sanford E. 2017. Transcriptomic responses to seawater acidification among sea urchin populations inhabiting a natural $\mathrm{pH}$ mosaic. Molecular Ecology 26:2257-2275.

Fabricius KE, Noonan SHC, Abrego D, Harrington L, De'ath G. 2017. Low recruitment due to altered settlement substrata as primary constraint for coral communities under ocean acidification. Proceedings of the Royal Society B: Biological Sciences 284.

Feely RA, Doney SC, Coole SR. 2009. Ocean Acidification: Present Conditions and Future Changes in a High-CO 2 world. Oceanography. 22:36-47.

Gladis-Schmacka F, Glatzel S, Karsten U, Böttcher H, Schumann R. 2014. Influence of local climate and climate change on aeroterrestrial phototrophic biofilms. Biofouling. 30:401-414.

Hadfield MG. 2011. Biofilms and Marine Invertebrate Larvae: What Bacteria Produce That Larvae Use to Choose Settlement Sites. Annu Rev Mar Sci. 3:453-470.

Hallegraeff GM. 2010. Ocean Climate Change, Phytoplankton Community Responses, and Harmful Algal Blooms: A Formidable Predictive Challenge1. J Phycol. 46:220-235.

Hasegawa H, Chatterjee A, Cui Y, Chatterjee AK. 2005. Elevated temperature enhances virulence of Erwinia carotovora subsp. carotovora strain EC153 to plants and stimulates production of the quorum sensing signal, $\mathrm{N}$-acyl homoserine lactone, and extracellular proteins. Appl Environ Microbiol. 71:4655-4663.

Hay M. 2009. Marine Chemical Ecology: Chemical signals and cues structure marine populations, communities, and ecosystems. Annual Review Mar Sci.1: 193-212. 
Hellmann JJ, Byers JE, Bierwagen BG, Dukes JS. 2008. Cinco Consecuencias Potenciales del Cambio Climático para Especies Invasoras. Conserv Biol. 22:534-543.

Hmelo LR, Mincer TJ, Van Mooy BAS. 2011. Possible influence of bacterial quorum sensing on the hydrolysis of sinking particulate organic carbon in marine environments. Environ Microbiol Rep. 3:682-688.

Hochachka PW, Somero GN. 2002. Biochemical adaptation: mechanism and process in physiological evolution. Oxford University Press, 480p.

Hoegh-Guldberg O, Mumby PJ, Hooten AJ, Steneck RS, Greenfield P, Gomez E, Harvell CD, Sale PF, Edwards AJ, Caldeira K, et al. 2007. Coral Reefs Under Rapid Climate Change and Ocean Acidification. Science. 318:1737-1742.

IPCC 2013. Climate Change 2013: The Physical Science Basis. Contribution of Working Group I to the Fifth Assessment Report of the Intergovernmental Panel on Climate Change. Cambridge University Press, Cambridge, United Kingdom and New York, NY, USA.

Iyer PV, Ananthanarayan L. 2008. Enzyme stability and stabilization-Aqueous and nonaqueous environment. Process Biochem. 43:1019-1032.

Keller RP, Drake JM, Drew MB, Lodge DM. 2011. Linking environmental conditions and ship movements to estimate invasive species transport across the global shipping network. Divers Distrib. 17:93-102.

Kimes NE, Grim CJ, Johnson WR, Hasan NA, Tall BD, Kothary MH, Kiss H, Munk AC, Tapia R, Green L, et al. 2012. Temperature regulation of virulence factors in the pathogen Vibrio coralliilyticus. ISME J. 6:835-846.

Kim TW, Micheli F. 2013. Decreased solar radiation and increased temperature combine to facilitate fouling by marine non-indigenous species. Biofouling. 29:501-512.

Kushmaro A, Banin E, Loya Y, Stackebrandt E, Rosenberg E. 2001. Vibrio shiloi sp. nov., the causative agent of bleaching of the coral Oculina patagonica. Int J Syst Evol Microbiol. 51:1383-1388.

Lane AC, Mukherjee J, Chan VBS, Thiyagarajan V. 2013. Decreased pH does not alter metamorphosis but compromises juvenile calcification of the tube worm Hydroides elegans. Mar Biol. 160:1983-1993.

Lasserre F, Pelletier S. 2011. Polar super seaways? Maritime transport in the Arctic: an analysis of shipowners' intentions. J Transp Geogr. 19:1465-1473.

Lau SCK, Thiyagarajan V, Cheung SCK, Qian P. 2005. Roles of bacterial community composition in biofilms as a mediator for larval settlement of three marine invertebrates. Aquat Microb Ecol. 38:41-51. 
Leliaert F, Zhang X, Ye N, Malta E, Engelen AH, Mineur F, Verbruggen H, De Clerck O. 2009. Research note: Identity of the Qingdao algal bloom. Phycol Res. 57:147-151.

Malaeb L, Le-Clech P, Vrouwenvelder JS, Ayoub GM, Saikaly PE. 2013. Do biologicalbased strategies hold promise to biofouling control in MBRs? Water Res. 47:5447-5463.

Martins MS, Massocato TF, Horta PA, Barufi JB. 2016. First record of red macroalgae bloom in Southern Atlantic Brazil. Algae 31(1): 33-39.

Mayer AMS, Rodríguez AD, Taglialatela-Scafati O, Fusetani N. 2013. Marine pharmacology in 2009-2011: marine compounds with antibacterial, antidiabetic, antifungal, anti-inflammatory, antiprotozoal, antituberculosis, and antiviral activities; affecting the immune and nervous systems, and other miscellaneous mechanisms of action. Mar Drugs. 11:2510-2573.

McCoy SJ, Ragazzola F. 2014. Skeletal trade-offs in coralline algae in response to ocean acidification. Nature Climate Change. 4:719-723.

McDonald MR, McClintock JB, Amsler CD, Rittschof D, Angus RA, Orihuela B, Lutostanski K. 2009. Effects of ocean acidification over the life history of the barnacle Amphibalanus amphitrite. Mar Ecol Prog Ser. 385:179-187.

Milazzo M, Rodolfo-Metalpa R, Chan VBS, Fine M, Alessi C, Thiyagarajan V, HallSpencer JM, Chemello R. 2014. Ocean acidification impairs vermetid reef recruitment. Scientific Reports 4:4189.

Miller MB, Bassler BL. 2001. Quorum sensing in bacteria. Annu Rev Microbiol. 55:165199.

Moree WJ, Phelan VV, Wu C-H, Bandeira N, Cornett DS, Duggan BM, Dorrestein PC. 2012. Interkingdom metabolic transformations captured by microbial imaging mass spectrometry. Proc Natl Acad Sci. 109:13811-13816.

Nannini M, De Marchi L, Lombardi C, Ragazzola F. 2015. Effects of thermal stress on the growth of an intertidal population of Ellisolandia elongata (Rhodophyta) from N-W Mediterranean Sea. Mar Environ Res 112, Part B:11-19.

Nardone JA, Patel S, Siegel KR, Tedesco D, McNicholl CG, O'Malley J, Herrick J, Metzler RA, Orihuela B, Rittschof D, Dickinson GH. 2018. Assessing the Impacts of Ocean Acidification on Adhesion and Shell Formation in the Barnacle Amphibalanus amphitrite. Frontiers in Marine Science, section Marine Molecular Biology and Ecology. https://doi.org/10.3389/fmars.2018.00369

Nasrolahi A, Stratil SB, Jacob KJ, Wahl M. 2012. A protective coat of microorganisms on macroalgae: inhibitory effects of bacterial biofilms and epibiotic microbial assemblages on barnacle attachment. FEMS Microbiol Ecol. 81:583-595. 
Niyogi S, Biswas S, Sarker S, Datta AG. 2001. Seasonal variation of antioxidant and biotransformation enzymes in barnacle, Balanus balanoides, and their relation with polyaromatic hydrocarbons. Mar Environ Res. 52:13-26.

O’Donnell MJ, George MN, Carrington E. 2013. Mussel byssus attachment weakened by ocean acidification. Nat Clim Change. 3:587-590.

Okamura D, Mori Y, Hashimoto T, Hori K. 2010. Effects of microbial degradation of biofoulants on microfiltration membrane performance in a membrane bioreactor. Environ Sci Technol. 44:8644-8648.

Okazaki RR, Towle EK, van Hooidonk R, Mor C, Winter RN, Piggot AM, Cunning R, Baker AC, Klaus JS, Swart PK, Langdon C. 2017. Species-specific responses to climate change and community composition determine future calcification rates of Florida Keys reefs. Global Change Biology 23:1023-1035.

Paerl HW, Huisman J. 2009. Climate change: a catalyst for global expansion of harmful cyanobacterial blooms. Environ Microbiol Rep. 1:27-37.

Parker LM, Ross PM, O’Connor WA. 2011. Populations of the Sydney rock oyster, Saccostrea glomerata, vary in response to ocean acidification. Mar Biol. 158:689-697.

Patil SA, Harnisch F, Koch C, Hübschmann T, Fetzer I, Carmona-Martínez AA, Müller S, Schröder U. 2011. Electroactive mixed culture derived biofilms in microbial bioelectrochemical systems: The role of $\mathrm{pH}$ on biofilm formation, performance and composition. Bioresour Technol. 102:9683-9690.

Peck LS, Clark MS, Power D, Reis J, Batista FM, Harper EM. 2015. Acidification effects on biofouling communities: winners and losers. Glob Change Biol. 21(5):1907-1913.

Poloczanska ES, Butler AJ. 2009. Biofouling and Climate Change. In: Dürr S., Thomason J.C., editors. Biofouling, Wiley-Blackwell, p. 333-347.

Price PB, Sowers T. 2004. Temperature dependence of metabolic rates for microbial growth, maintenance, and survival. Proc Natl Acad Sci U S A. 101:4631-4636.

Qian P-Y, Lau SCK, Dahms H-U, Dobretsov S, Harder T. 2007. Marine biofilms as mediators of colonization by marine macroorganisms: implications for antifouling and aquaculture. Mar Biotechnol N Y N. 9:399-410.

Rajkumar M, Prasad MNV, Swaminathan S, Freitas H. 2013. Climate change driven plant-metal-microbe interactions. Environ Int. 53:74-86.

Richlen ML, Morton SL, Jamali EA, Rajan A, Anderson DM. 2010. The catastrophic 2008-2009 red tide in the Arabian gulf region, with observations on the identification and phylogeny of the fish-killing dinoflagellate Cochlodinium polykrikoides. Harmful Algae. 9:163-172. 
Richmond MD, Seed R. 1991. A review of marine macrofouling communities with special reference to animal fouling. Biofouling. 3:151-168.

Rittschof D. 2017.Trypsins: Keystone Enzymes in Marine Communities. Enzymology and Protein Science. JSM Enzymol Protein Sci 2(1): 1009

Saderne V, Wahl M. 2013. Differential Responses of Calcifying and Non-Calcifying Epibionts of a Brown Macroalga to Present-Day and Future Upwelling pCO2. PLoS ONE 8(7): e 70455. https://doi.org/10.1371/journal.pone.0070455

Saha M, Rempt M, Stratil SB, Wahl M, Pohnert G, Weinberger F. 2014. Defence Chemistry Modulation by Light and Temperature Shifts and the Resulting Effects on Associated Epibacteria of Fucus vesiculosus. PLoS ONE. 9:e105333.

Salta M, Wharton JA, Blache Y, Stokes KR, Briand J-F. 2013. Marine biofilms on artificial surfaces: structure and dynamics. Environ Microbiol. 15:2879-2893.

Schultz MP, Bendick JA, Holm ER, Hertel WM. 2011. Economic impact of biofouling on a naval surface ship. Biofouling. 27:87-98.

Sievers M, Dempster T, Fitridge I, Keough MJ. 2014. Monitoring biofouling communities could reduce impacts to mussel aquaculture by allowing synchronisation of husbandry techniques with peaks in settlement. Biofouling. 30:203-212.

Singh S, Singh A, Aziz MA, Waheed SM, Bhat R, Bhatnagar R. 2004. Thermal inactivation of protective antigen of Bacillus anthracis and its prevention by polyol osmolytes. Biochem Biophys Res Commun. 322:1029-1037.

Sorte CJB, Williams SL, Zerebecki RA. 2010. Ocean warming increases threat of invasive species in a marine fouling community. Ecology. 91:2198-2204.

Stachowicz JJ, Terwin JR, Whitlatch RB, Osman RW. 2002. Linking climate change and biological invasions: Ocean warming facilitates nonindigenous species invasions. Proc Natl Acad Sci. 99:15497-15500.

Tedesco D, Nardone JA, Siegel KR, Patel S, Orihuela B, Rittschof D, Dickinson GH. 2017. Effects of ocean acidification and temperature on biomineralization and adhesion in the barnacle, Amphibalanus amphitrite. Presented at 46th Benthic Ecology Meeting, Myrtle Beach, South Carolina.

Trepos R, Pinori E, Berglin M, Svenson J, Coutinho R, Lausmaa J, Hellio C. 2014. Innovative approaches for the development of new copper-free marine antifouling paints. Journal of ocean technology, J Ocean Technol. 9:7-18

Toren A, Landau L, Kushmaro A, Loya Y, Rosenberg E. 1998. Effect of Temperature on Adhesion of Vibrio Strain AK-1 to Oculina patagonica and on Coral Bleaching. Appl Environ Microbiol. 64:1379-1384. 
Uroz S, Chhabra SR, Cámara M, Williams P, Oger P, Dessaux Y. 2005. NAcylhomoserine lactone quorum-sensing molecules are modified and degraded by Rhodococcus erythropolis W2 by both amidolytic and novel oxidoreductase activities. Microbiol Read Engl. 151:3313-3322.

Wahl M, Goecke F, Labes A, Dobretsov S, Weinberger F. 2012. The second skin: ecological role of epibiotic biofilms on marine organisms. Front Microbiol. 3:292.

Wahl M., Saderne V, Sawall Y. 2015. How good are we at assessing the impact of ocean acidification in coastal systems? Limitations, omissions and strengths of commonly used experimental approaches with special emphasis on the neglected role of fluctuations. Mar Freshwater Res 67(1): 25-36.

Wahl M, Scheider Covacha S, Saderne V, Hiebenthal C, Muller JD, Pansch C, Sawall Y. 2017. Macroalgae may mitigate ocean acidification effects on mussel calcification by increasing $\mathrm{pH}$ and its fluctuations. Limnology and Oceanography 63 (1): 3-21.

Ware C, Berge J, Sundet JH, Kirkpatrick JB, Coutts ADM, Jelmert A, Olsen SM, Floerl O, Wisz MS, Alsos IG. 2014. Climate change, non-indigenous species and shipping: assessing the risk of species introduction to a high-Arctic archipelago. Divers Distrib. 20:10-19.

Waters CM, Bassler BL. 2005. Quorum sensing: Cell-to-Cell Communication in Bacteria. Annu Rev Cell Dev Biol. 21:319-346.

Webb JS, Givskov M, Kjelleberg S. 2003. Bacterial biofilms: prokaryotic adventures in multicellularity. Curr Opin Microbiol. 6:578-585.

Webster NS, Negri AP, Flores F, Humphrey C, Soo R, Botté ES, et al. 2013. Near-Future Ocean acidification causes differences in microbial associations within diverse coral reef taxa. Environ Microbiol Rep. 5:243-251. doi: 10.1111/1758-2229.12006.

Whalan S, Webster NS. 2014. Sponge larval settlement cues: the role of microbial biofilms in a warming ocean. Sci Rep 4.

White PA, Kalff J, Rasmussen JB, Gasol JM. 1991. The effect of temperature and algal biomass on bacterial production and specific growth rate in freshwater and marine habitats. Microb Ecol. 21:99-118.

Wieczorek SK, Murray AW, Todd CD. 1996. Seasonal variation in the effects of hard substratum biofilming on settlement of marine invertebrate larvae. Biofouling. 10:309330 .

Williams P. 2007. Quorum sensing, communication and cross-kingdom signalling in the bacterial world. Microbiology. 153:3923-3938. 
Wong KKW, Lane AC, Leung PTY, Thiyagarajan V. 2011. Response of larval barnacle proteome to CO2-driven seawater acidification. Comp Biochem Physiol Part D Genomics Proteomics. 6:310-321.

Yang LH, Miao L, Lee OO, Li X, Xiong H, Pang K-L, Vrijmoed L, Qian P-Y. 2007. Effect of culture conditions on antifouling compound production of a sponge-associated fungus. Appl Microbiol Biotechnol. 74:1221-1231.

Yates EA, Philipp B, Buckley C, Atkinson S, Chhabra SR, Sockett RE, Goldner M, Dessaux Y, Cámara M, Smith H, Williams P. 2002. N-acylhomoserine lactones undergo lactonolysis in a pH-, temperature-, and acyl chain length-dependent manner during growth of Yersinia pseudotuberculosis and Pseudomonas aeruginosa. Infect Immun. 70:5635-5646.

Yebra DM, Kiil S, Dam-Johansen K. 2004. Antifouling technology_past, present and future steps towards efficient and environmentally friendly antifouling coatings. Prog Org Coat. 50:75-104.

Yebra DM, Kiil S, Weinell CE, Dam-Johansen K. 2006. Dissolution rate measurements of sea water soluble pigments for antifouling paints: ZnO. Prog Org Coat. 56:327-337.

Zardus JD, Nedved BT, Huang Y, Tran C, Hadfield MG. 2008. Microbial biofilms facilitate adhesion in biofouling invertebrates. Biol Bull. 214:91-98.

Zhao X, Guo C, Han Y, Che Z, Wang Y, Wang X. et al. 2017. Ocean acidification decreases mussel byssal attachment strength and induces molecular byssal responses. Mar. Ecol. Prog. Ser. 565: 67-77. doi: 10.3354/meps11992

Zhou Y, Han L-R, He H-W, Sang B, Yu D-L. et al. 2018. Effects of Agitation, Aeration and Temperature on Production of a Novel Glycoprotein GP-1 by Streptomyces kanasenisi ZX01 and Scale-Up Based on Volumetric Oxygen Transfer Coefficient. Molecules. 23(1):125

Zobell CE, Allen EC. 1935. The Significance of Marine Bacteria in the Fouling of Submerged Surfaces. J Bacteriol. 29:239-251.

Zvyagintsev AYu. 2003. Introduction of Species into the Northwestern Sea of Japan and the Problem of Marine Fouling. Rus J Mar Biol 29: 10-21. 


\section{Tables and figures}

Table 1. Impact of factors associated with global climate change on bioactive molecules and microfouling communities

\begin{tabular}{|c|c|c|}
\hline \multirow[t]{2}{*}{ Factors } & \multicolumn{2}{|c|}{\begin{tabular}{|l} 
Proposed activity on \\
\end{tabular}} \\
\hline & Bioactive molecules & Microfouling communities \\
\hline $\begin{array}{l}\text { Increase of level of } \mathrm{CO}_{2} \text { and } \\
\text { ocean acidification }\end{array}$ & $\begin{array}{l}\text { Weakening of adhesion } \\
\text { proteins (O'Donnell et al. } \\
\text { 2013; Tedesco et al. } \\
\text { 2017); change stability of } \\
\text { chemical signals (Iyer \& } \\
\text { Ananthanarayan 2008; } \\
\text { Decho et al. 2009) }\end{array}$ & $\begin{array}{l}\text { Changes in marine communities } \\
\text { (Patil et al. 2011; Webster et al. } \\
\text { 2013); lower diatom densities } \\
\text { (Peck et al. 2015). }\end{array}$ \\
\hline $\begin{array}{l}\text { Increase of water and } \\
\text { atmospheric temperatures }\end{array}$ & $\begin{array}{l}\text { Enhance biodegradation of } \\
\text { molecules due to microbes } \\
\text { (Decho et al. 2010); } \\
\text { change enzyme activity } \\
\text { (Niyogi et al. 2001; Wong } \\
\text { et al. 2011) }\end{array}$ & $\begin{array}{l}\text { Changes in community structure } \\
\text { (Stratil et al. 2013) and effect on } \\
\text { larval settlement (Lau et al. } \\
\text { 2005; Whalan \& Webster 2014); } \\
\text { lower community diversity } \\
\text { (Stratil et al. 2013); disruption of } \\
\text { host -microbiome interactions } \\
\text { (Stratil et al. 2013); increase } \\
\text { growth of marine pathogens } \\
\text { (Toren et al. 1998; Kushmaro et } \\
\text { al. 2001) }\end{array}$ \\
\hline $\begin{array}{l}\text { Increased water turbulence and } \\
\text { severe weather conditions }\end{array}$ & $\begin{array}{l}\text { Changes in production of } \\
\text { compounds and their } \\
\text { dispersal (Zhou et al. } \\
\text { 2018; Batista et al. 2018) }\end{array}$ & $\begin{array}{l}\text { Disturbance of communities; } \\
\text { changes in structure of microbial } \\
\text { communities (Gladis-Schmacka } \\
\text { et al. 2014; Batista et al. 2018) }\end{array}$ \\
\hline New ship routes & No direct effect & $\begin{array}{l}\text { Increase introduction of invasive } \\
\text { species (Sorte et al. 2010); } \\
\text { changes in communities } \\
\text { (Zvyagintsev 2003) }\end{array}$ \\
\hline Increased pollution & $\begin{array}{l}\text { Change concentrations of } \\
\text { compounds (Niyogi et al. } \\
\text { 2001) }\end{array}$ & $\begin{array}{l}\text { Increase chances of algal blooms } \\
\text { (Paerl \& Huisman 2009) and } \\
\text { decrease in diversity of } \\
\text { biofouling communities } \\
\text { (Dobretsov 2015) }\end{array}$ \\
\hline Combine effect & Rather unpredictable & $\begin{array}{l}\text { Rather unpredictable and mostly } \\
\text { negative }\end{array}$ \\
\hline
\end{tabular}


Table 2. Impact of climate change on antifouling industry

\begin{tabular}{|l|l|}
\hline \multicolumn{1}{|c|}{$\begin{array}{c}\text { Factors associated with } \\
\text { climate change }\end{array}$} & \multicolumn{1}{|c|}{ Proposed effect on antifouling coatings } \\
\hline Sea water temperature rise & $\begin{array}{l}\text { Increase in polishing and biocide leaching rates; } \\
\text { Earlier coating exhaustion; } \\
\text { Changes in coating efficiency and the leached layer } \\
\text { thickness }\end{array}$ \\
\hline Sea water acidification & $\begin{array}{l}\text { Decrease in hydrolysis reaction rate for both acrylate- } \\
\text { and rosin-based binders with decrease of polishing } \\
\text { rates; } \\
\text { Potentially lower dissolution rates for hydrolyzing } \\
\text { particulate organic biocides; } \\
\text { Increase in Cu } 2 \mathrm{O} \text { and ZnO dissolution rates; } \\
\text { Increase in thickness of biocide-leached layer, with } \\
\text { negative effects on antifouling performance }\end{array}$ \\
\hline Antensification of water \\
turbulence and upwelling \\
routes
\end{tabular}




\section{Figure legends}

Figure 1. Percent of biofouling publications dealing with climate change. The research was performed using Google Scholar for the period of 2000 - 2018. Our search key words were "climate change" and "biofouling".

Figure 2. Percent of climate change-related biofouling publications dealing with different levels of biological organizations: molecular (compounds), organism (species), population and community. The research was performed using Web of Science for all publications for the period of 2000 - 2018. The search key words were "climate change" and one of the terms.

Figure 3. Schematic diagram showing the impact of climate change on biofouling molecules, communities and antifouling industry. 


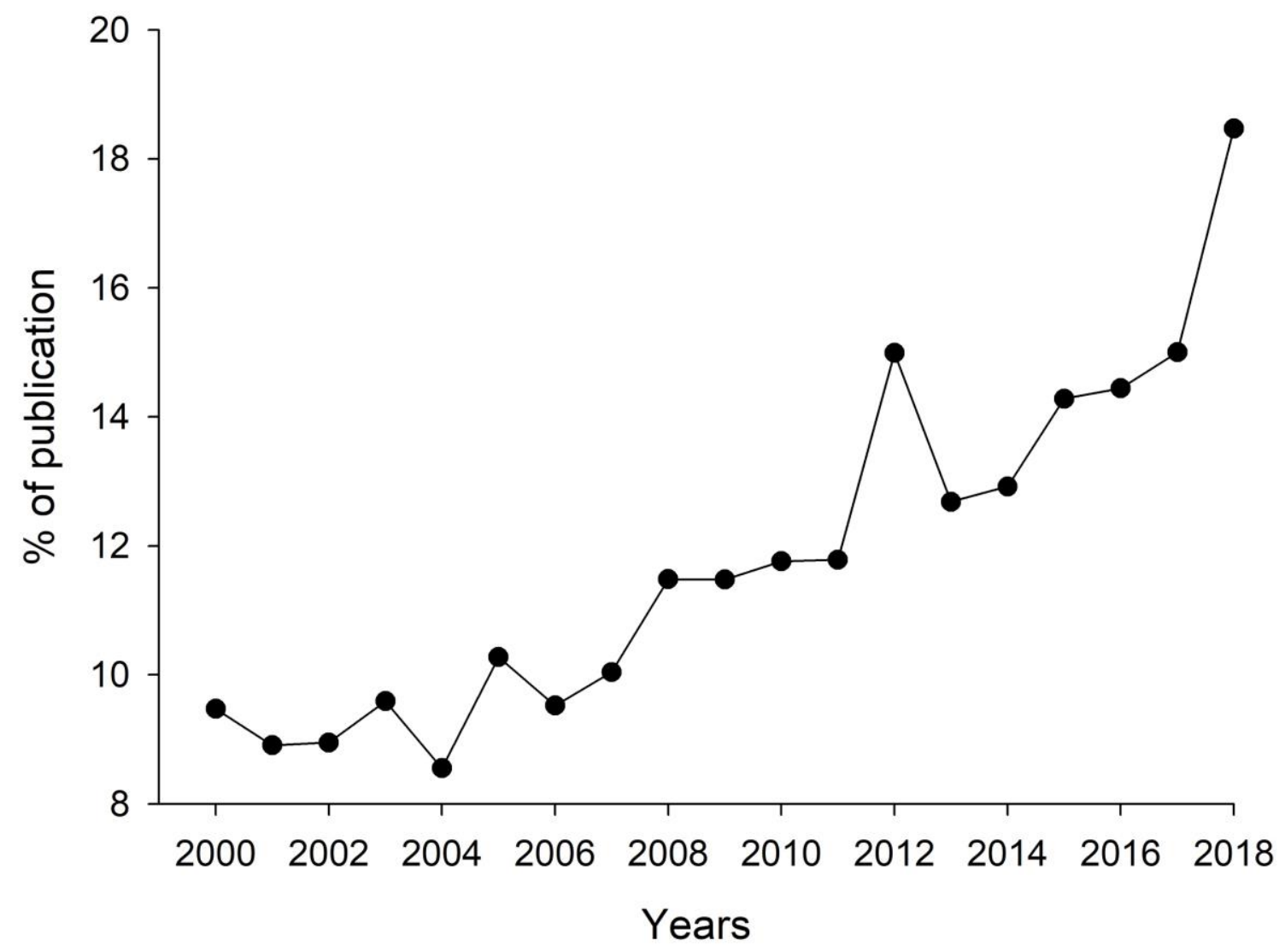

Figure 1 


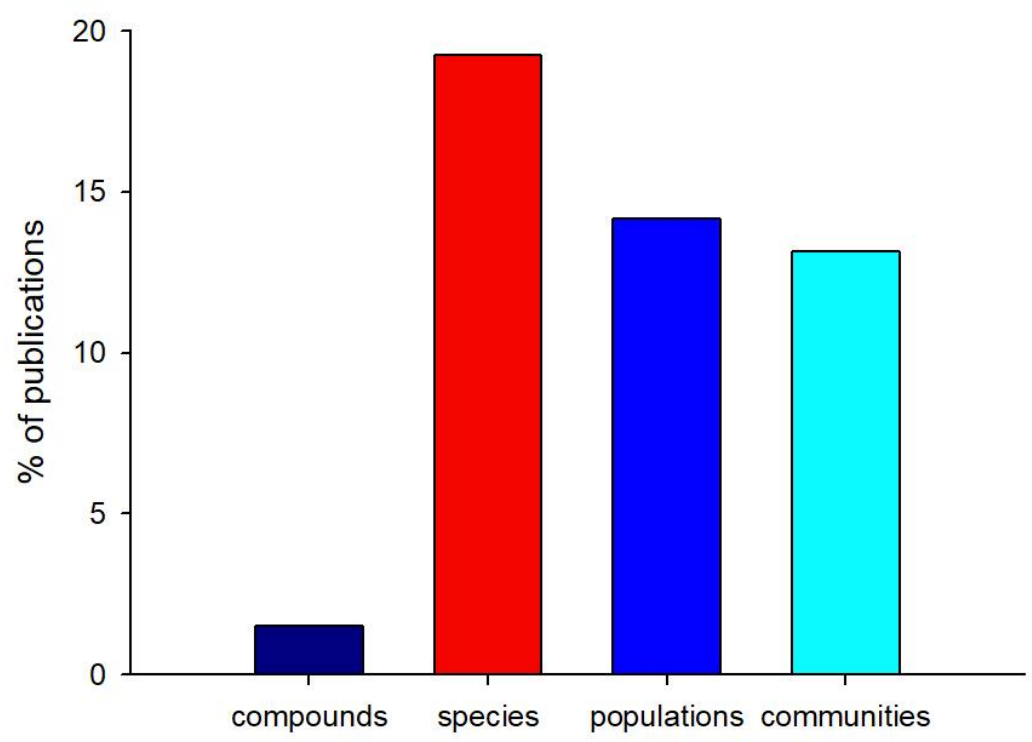

Figure 2. 
Figure 3.

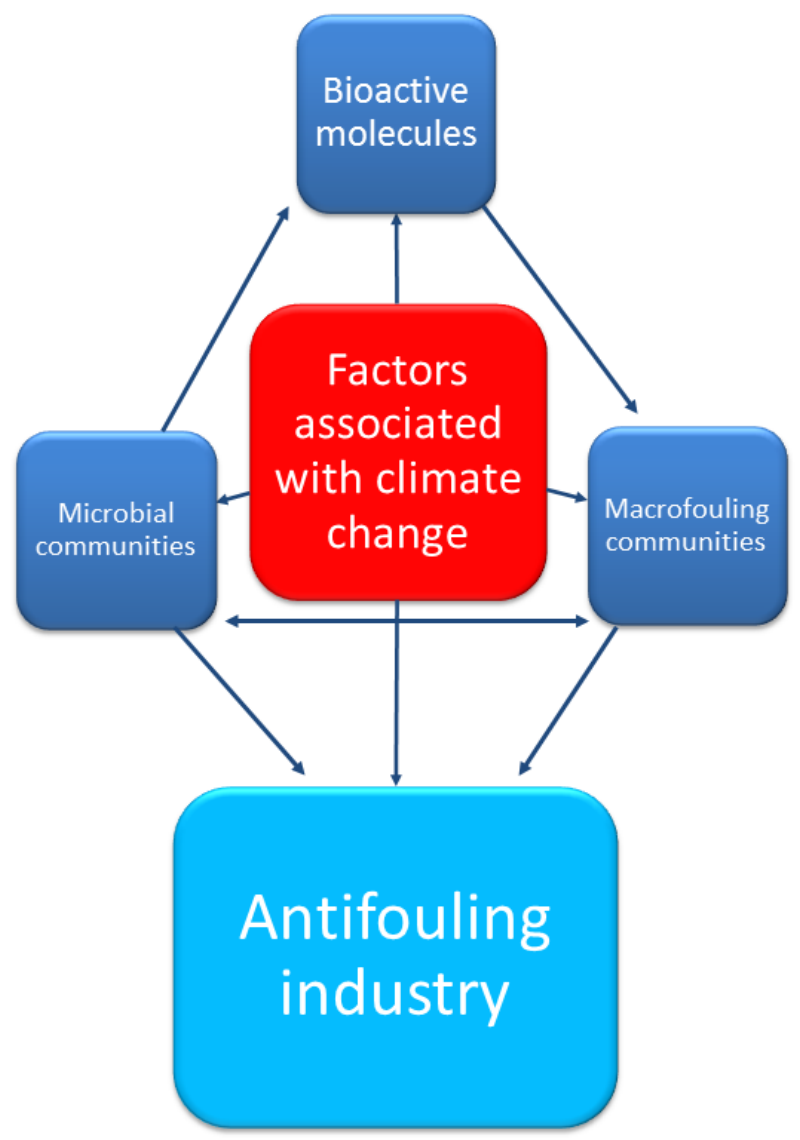

